\title{
フレイル健診2020
}

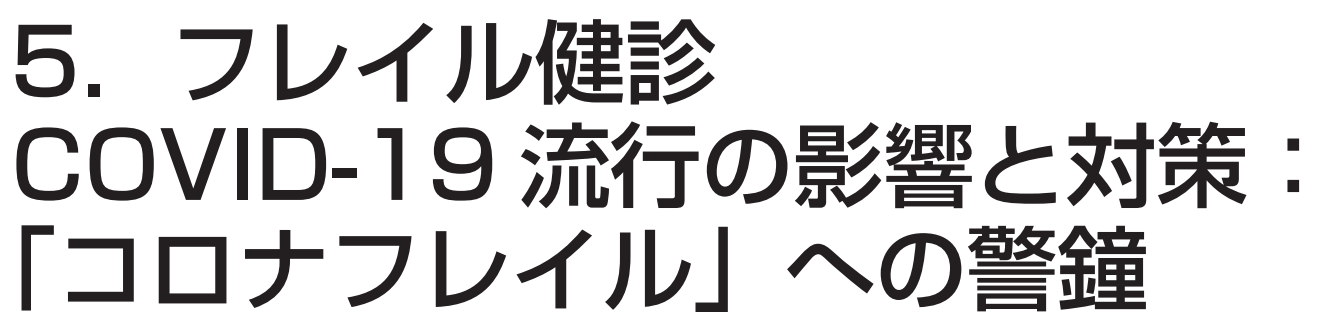

Influence and measures of COVID-19 pandemic

-Alert against CORONA-related frailty progression-

\section{飯島 勝矢}

\section{要約}

新型コロナウイルス感染症 (COVID-19) 流行の問題は, 確かに高齢者において重症化しやすく, 結果的 に残念ながら命を落とした方々も少なくない，しかし，新たな感染症の課題を新たに示しているだけではな く, 流行前から持ち合わせていた様々な地域課題や社会課題をより早期に見える化したのであろう. ポスト コロナ社会を見据え, 個々の国民に何を伝え，さらに新たな地域社会づくりにどう反映させるのか，ここは 大きな分岐点になるだろう. この課題は, ポストコロナ時代において, 人のQOL のあり方はどう変わってい くべきかを意味している. ワクチンや治療薬の確立と同時に, 真の人間中心社会に向けて, 「我々の忘れては ならない原点」と「次世代の新しい地域コミュニティ像（新たなデジタル社会含む)」の両方を実現しながら, 人と人との心を近づけ, 絆を感じ, 豊かな社会にむけた新たな価値を全世代に創造してくれることを期待し たい.

Key words 自肃生活長期化, 生活不活発, フレイル, 健康二次被害, 健全な地域活動

（日老医誌 2021；58：228-234）

はじめに

新型コロナウイルス感染症 (COVID-19) 問題が 2020 年に起こり，世界規模の非常事態となった. なかなか 終息の気配がなく，日常の生活は簡単には元に戻るこ とはできそうもない。第 1 波から第 3 波にかけて，我 が国でも多くの経験を積み，感染予防を徹底した各自 の新たな生活様式（いわゆるニューノーマル）が促さ
れ，医療体制の整備も進めてきた。しかし，高齢者の なかには非常に重症化しやすく, よりケア体制も必要 とされるケースも少なくなく，まだ気を緩めることな く社会全体で守っていく必要がある。ささらに，今回の コロナ問題は高齢者の身体だけではなく, 地域社会自 体にも大きな負の影響を及ぼしている．自肃生活が長 期化し, 同時に地域活動も中止に追い込まれてしまい, 人との交流も減ってしまっている，このコロナ問題は

東京大学高齢社会総合研究機構機構長・未来ビジョン研究センター教授 連絡責任者：飯島勝矢 東京大学高齢社会総合研究機構〔干113-8656 東京都文京区本郷 7-3-1 工学部 8 号館 713〕 e-mail: iijima@iog.u-tokyo.ac.jp doi: 10.3143 /geriatrics.58.228 


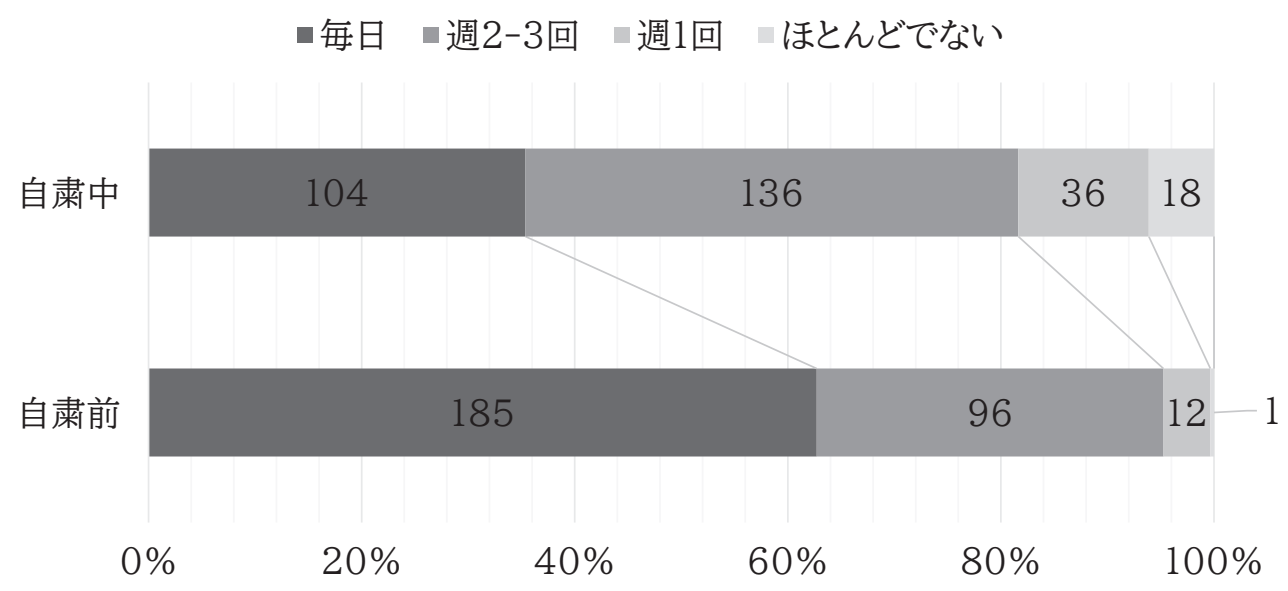

図 1 COVID-19による外出自肃要請が高齢者の健康行動を阻害

単なる新たな感染症の課題を示しているだけではな く, 流行の前から持ち合わせていた様々な地域課題や 社会課題をより早期に見える化したのだろう。ポスト コロナ社会を見据え，どのように地域社会を再構築し ていけば良いのだろうか.

\section{COVID-19 により地域在住高齢者に何 が起きているのか}

高齢者の自肃生活長期化による活動低下（いわゆる 生活不活発）の傾向が，第 1 波の 4 月頃に認められ， 6 月頃には戻ってきていること等も山田らによって報 告されている ${ }^{122)}$. 連日にわたるメデイア報道も受け, 思っている以上に日常生活を慎重に考元, 結果的に不 活発になってしまっていたのだろう.

さらに，筆者が率いるフレイル予防研究チームでも 同様のデー夕を得ている。我々は地域の元気シニアを フレイルサポーターとして養成し,「高齢住民主体のフ レイルチェック活動を軸とした健康長寿まちづくり」 を全国の自治体に向けて推進している。この取り組み は, 我々のコホート研究からのエビデンスを基に, 食/ 栄養，口腔機能，運動を含めた身体活動，社会性（社 会参加と人とのつながり）などの多面的な要素を包含 している，地域の通いの場などにおいて，高齢住民だ けでワイワイとした雲囲気の中で，フレイルサポー ターによりチェックを行い，一緒に気づき，自分事化 をしていくことを狙ったものである. 現在, 全国で 73
自治体に導入し展開中である，その導入自治体におい て，フレイルチェックを(一時的に中止するも）再開 してくれている自治体が幾つも存在し, 最新情報が集 約されてきている，単なる感染リスクだけではなく， 高齢者への自肃生活長期化による顕著な生活不活発を 基盤とするフレイル化拉よびフレイル状態の悪化（い わゆる健康二次被害,『コロナフレイル』とも言える) が明確なエビデンスとして見えてきた。具体的に，以 下に 3 つの結果が見えてきた.

1つ目として, 東京都内の高齢化率の高い集合住宅 に拄まいの高齢者 294 名 (男性 144 名；女性 150 名) に対して，自記式質問票配布による調査を行った（図 1). 外出自肃要請・緊急事態宣言の発令前後で 121 名 （41.2\%）の外出頻度が低下した. 自肃前より外出頻度 が週 1 回以下の閉じこもり傾向になった 13 名を除い た 281 名の内， 41 名（13.9\%）は新たに閉じこもり傾 向になった，緊急事態宣言中も適度に外出していた高 齢者と比較すると, 新たに閉じこもり傾向となった 41 名では, 運動ができない人は 5.3 倍, 会話の機会が減っ た人が 2.1 倍，バランスの取れた健康的な食事を取れ ていない人が 2.6 倍多かった。

2 つ目の別の導入自治体に打いて, 活動自肃生活前 後でサルコペニア進行の可能性が示唆された（図 2). 神奈川県内のある自治体に押いて, 在住高齢者 124 名 （平均年齢 $77.0(5.2)$ 歳；女性 71\%) を対象に, COVID19 流行前に得たデータとコロナ禍（2020 年 6 月〜8 月）で得たデー夕を比較した。 30 名（22.4\%）に筋肉 


\section{コロナ禍での筋肉量の減少}

（指輪つかテスト）

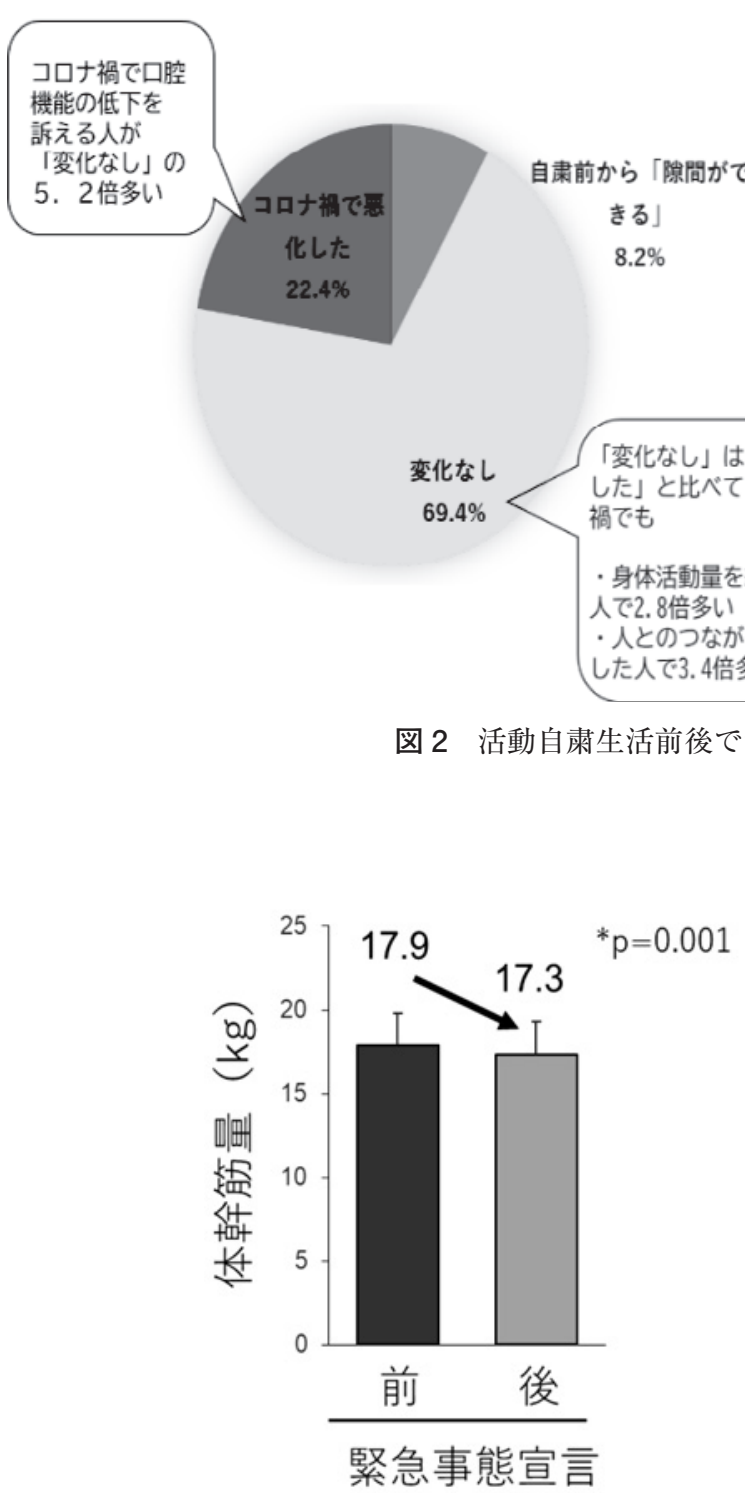

コロナ禍での歩行速度の低下

(同年代・同性と比ベて歩行速度が遅いと思うか)

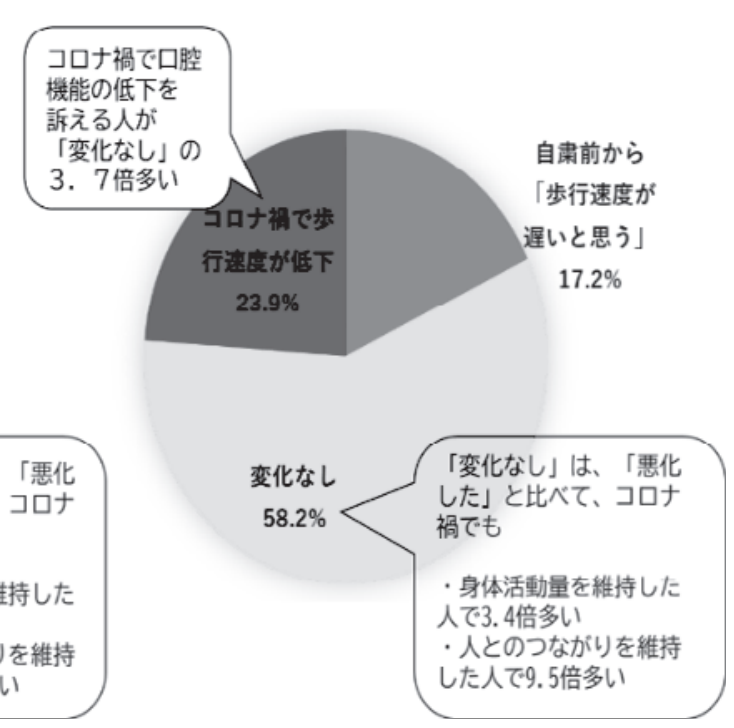

ルコペニア進行の可能性

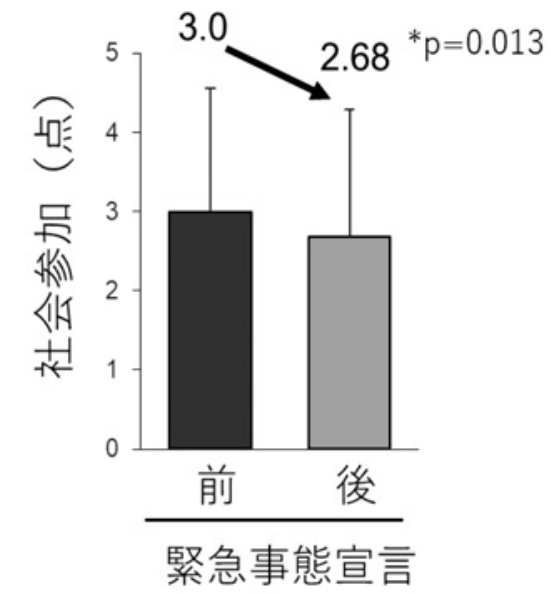

図 3 外出自肃により約半年で体幹筋量の有意な低下

量減少がみられ，32 名（23.0\%）が歩行速度低下を新 たに訴え, 同時に口腔機能低下を訴える人が多かった。

一方で，コロナ禍に打いて身体活動量，人とのつなが りを維持していた人ほど，この傾向は低い傾向にあっ た。

前述の 2 つ自治体も含め, 全国フレイルチェック 実施自治体からのデー夕をまとめ, 2020 年 4 月緊急
事態宣言（第 1 回目）前後での身体計測值や社会参加 を比較してみた（図 3)。緊急事態宣言前（=COVID19 流行前 2019 年 10 月～ 2020 年 2 月）と解除後 (2020 年 7 月〜9月）に，全国フレイルチェック実施自治体 から 65 歳以上の高齢者 450 名を対象として, 骨格筋 量（体幹筋量および四肢筋量）の計測を行った。その 結果, 特に女性（130 名, 平均年齢 $80.9 \pm 6.3$ 歳）に 
（例）81歳女性

\begin{tabular}{|c|c|c|c|c|}
\hline 連番 & & 21 & 3 & \\
\hline 性別 & & 女 & & \\
\hline 受診日. & 2019.11 .19 & $\rightarrow$ & 2020.7 .20 & \\
\hline ゆひ輪つかテスト. & 际間がてきる & $\rightarrow$ & 囲めない (ちょうど囲める) & \\
\hline 栄養：健康に気ををつけた食事を心。 & はい & $\rightarrow$ & はい & \\
\hline 栄湌 : 野菜と主菜を每日2回以上. & はい & $\rightarrow$ & はい & \\
\hline 口腔：「たくあん」の固さの食品. & はい & $\rightarrow$ & はい & \\
\hline 口腔：お茶や汁物でむせることが. & いいえ & $\rightarrow$ & いいえ & \\
\hline 運動：30分の運動を週2曰、1. & はい & $\rightarrow$ & はい & \\
\hline 運動：身体活動を1日1時間以上. & はい & $\rightarrow$ & はい & \\
\hline 運動：(7同姓同年齢と比ベて歩く. & はい & $\rightarrow$ & はい & \\
\hline 社こ：昨年と比べて外出の回数が. & いいえ & $\rightarrow$ & はい & \\
\hline 社こ：1回/日以上は、誰かと一。 & はい & $\rightarrow$ & はい & \\
\hline 社こ：自分が活気に溢れていると. & いいえ & $\rightarrow$ & いいえ & \\
\hline 社こ：何よりもます、物忘れが気。 & いいえ & $\rightarrow$ & いいえ & \\
\hline & & & & \\
\hline 滑舌 (夕) 数值. & 6 & $\rightarrow$ & 4 & -2 \\
\hline 滑舌 (力) 数值. & 5.8 & $\rightarrow$ & 3.8 & -2 \\
\hline 滑舌 (夕)。 & 6.0以上 & $\rightarrow$ & 6.0未満 & \\
\hline 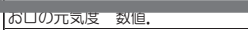 & 58 & $\rightarrow$ & 56 & -2 \\
\hline お口の元気、度. & $58 \sim 60$ 点 & $\rightarrow$ & $12 \sim 57$ 点 & \\
\hline 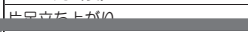 & $+7 z$ & the & $+\tau_{z}$ & \\
\hline らくくらはきき周囲長 数值. & 32 & $\rightarrow$ & 31 & -1 \\
\hline 倜囲長. & 十分な筋肉 & $\rightarrow$ & サルコペニアの可能性 & \\
\hline 握力 数值. & 21.3 & $\rightarrow$ & 19.4 & -1.9 \\
\hline 握力。 & 十分な筋肉 & $\rightarrow$ & サルコペニアの可能性 & \\
\hline 総筋量 数值. & 30.1 & $\rightarrow$ & 29.95 & -0.15 \\
\hline 体幹筋量 数値. & 17.75 & $\rightarrow$ & 15.8 & -1.95 \\
\hline 手足の筋肉量 数值。 & 6.3 & $\rightarrow$ & 6.46 & 0.16 \\
\hline 人とのつながり 数值. & 15 & $\rightarrow$ & 13 & -2 \\
\hline 人とのつながり. & $12 \sim 30$ 点 & $\rightarrow$ & 12 30点 & \\
\hline 組織参加 数值. & 1 & $\rightarrow$ & 1 & 0 \\
\hline 組織参加。 & 1 7点 & $\rightarrow$ & 1 7点 & \\
\hline 支え合い 数値. & 3 & $\rightarrow$ & 4 & 1 \\
\hline 支え合い。 & 1 3点 & $\rightarrow$ & 4点 & \\
\hline
\end{tabular}

\section{コ口ナ流行前}

2019年11月19日

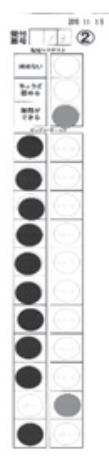

コロナ流行による 非常事態宣言後 2020年7月20日

図 4 COVID-19 流行前後のフレイルチェック結果の比較（81 歳女性の事例） (東京大学高齢社会総合研究機構 孫輔卿, 飯島勝矢. 事例提供)

\section{表 1}

\footnotetext{
(1)「新型コロナウイルス感染症」高齢者として気をつけた いポイント

(2)新型コロナウイルス感染症（COVID-19）流行期におい て高齢者が最善の医療およびケアを受けるための日本老 年医学会からの提言一ACP 実施のタイミングを考え る一

(3)新型コロナウイルス対応に関する居宅サービス（通所, 短期入所）利用者・ご家族向け注意喚起

(4)介護老人保健施設における新型コロナウイルス感染症対 応ガイド

(5)認知症をお持ちの方とそのご家族の方
}

おいて, 緊急事態宣言前に比べて, 解除後に体幹筋量 が有意に減少した。 ( - 約 $2 \mathrm{~kg}$ 減少の事例もあり：図 4）さらに社会参加においても有意な減少が認められ た.

以上のように, 感染者数が最も多い東京都内に限ら ず，複数の自治体において，コロナ禍での自肃生活長 期化による生活不活発および社会性の低下（地域交流
の低下）を基盤とし，サルコペニアを中心としたフレ イル化が進行している現象が多面的に認められた. こ のように，体幹筋量が顕著に低下することを定量的に 示したことで, サルコペニアを基盤とするフレイル進 行の速度や有病状態をより正確に把握することができ る.さらに，自宅でできる運動（自主努力だけではな く, オンライン型の非対面での運動も含む), 社会と のつながりを促すことで, コロナフレイルのリスクと 予防案をしっかりと国民に示す必要がある。

日本老年医学会からの様々なメッセー ジ発信

日本老年医学会から 2020 年に様々なメッセージが 発信されているので, 表 1 に一覧を示す.

外出自肃による身体機能の低下（フレイル）に関し ては(1)で示しており, すでに 2020 年 3 月の時点で分 

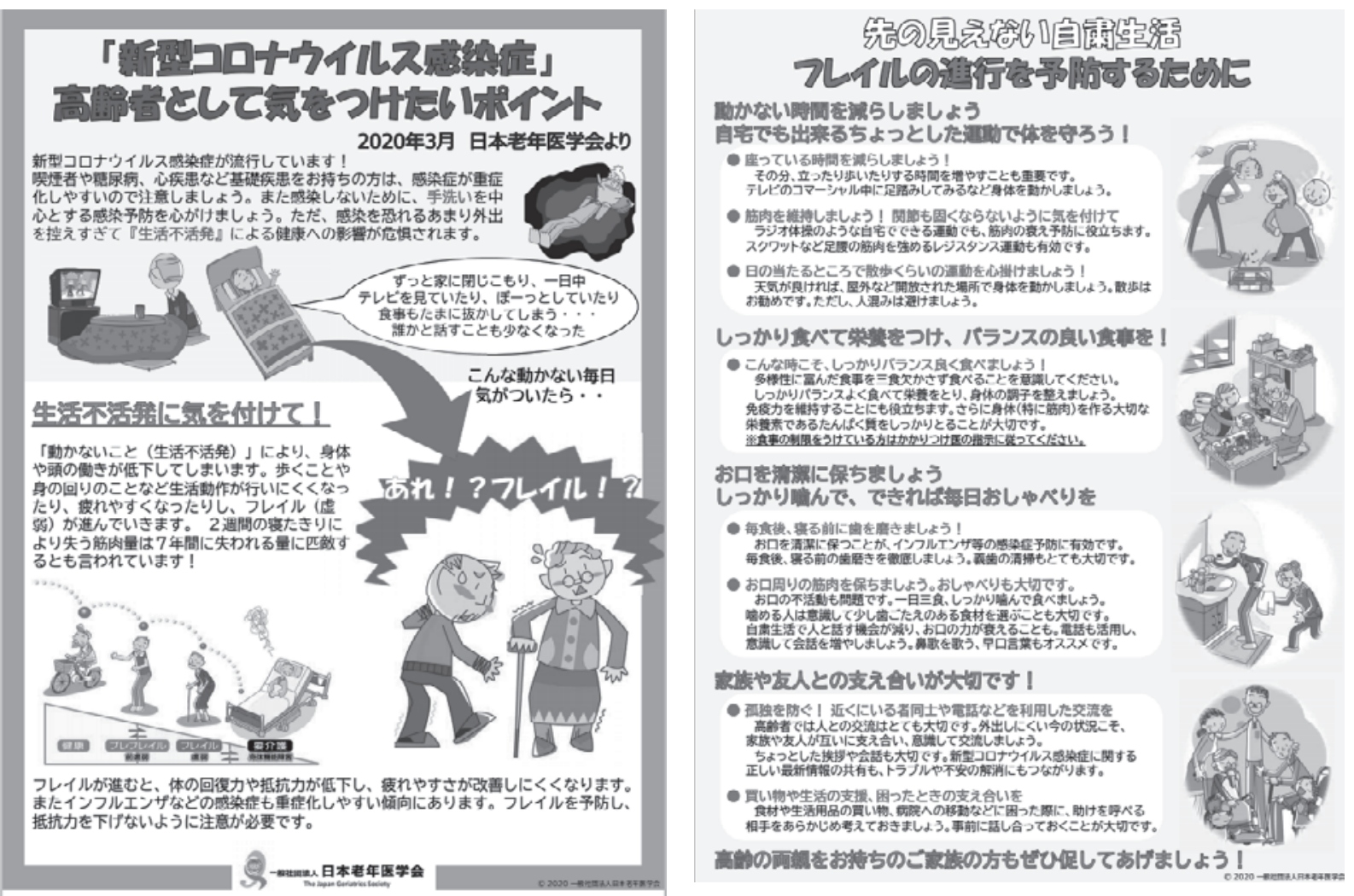

図 5 日本老年医学会からの様々なメッセージ発出

\section{国家戦略としての3つの「守る」}

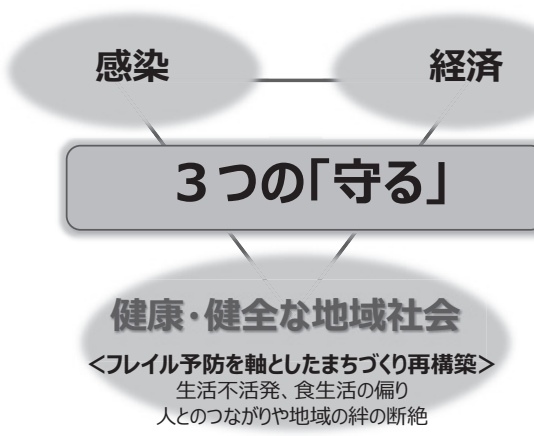

図 6 ポストコロナ社会における地域のニューノーマ ルの再構築

かりやすいリーフレット形式で出している $(\text { 図 5 })^{33}$. コロナ禍に扔いて危惧していたメッセージであった が，まさに予想通りの傾向が認められてきている。 ま た，高齢者で基礎疾患を抒持ちの方は重症化のリスク
がさらに高いことから，高齢者施設等を視野に感染予 防のための対応と感染経路の遮断等への指針を出して いる.

ウィズコロナ・ポストコロナ社会を見 据えた新たな地域像とは

COVID-19 による高齢者の生活不活発を基盤とする フレイル化, すなわち健康二次被害が現場のデータと ともに見えてきた，たしかに高齢者においてはコロナ 感染により重症化しやすいとも言われ，積極的にメ ディア報道を通して全国の国民に周知されてきた事実 がある。しかし，あまりにも感染を恐れるばかりに， 相対的に生活内容が極度の低活動・不活発に陥り, 知 らず知らずのうちにサルコペニアの進行を基盤とした フレイル状態の悪化が起こり, 移動能力の低下だけで はなく, 認知機能の低下, 次なる感染症への免疫力の 低下など，様々な負の連鎖が起こってしまう可能性が 
ある。

フレイル予防・対策のためには，まずは基本形とし て「栄養 (食と口腔機能), 身体活動（運動や社会活 動等), 社会参加 (人とのつながりが特に重要)」の 3 つの柱をいかに三位一体として底上げし，日常生活の 中に継続的に盛り込めるのかが鍵になる。 そこには,

(1)高齢者個々人へどのような情報を届け，改めて意識 変容・行動変容してもらうか, そして(2)全ての住民活 動が止まってしまっている地域コミュニティをどのよ うに前向きに再構築していくのか，この $2 つ の$ 視点が 重要になる.

あえてここで強調したいのは，自治体における止 まっている地域活動を単にいつ再開させるのかという 考え方ではなく,「ウィズコロナ・ポストコロナ社会を 見据えた新たな地域像をどう構築するのか」という視 点で考えるべきである．今後，全国の高齢者の方々に は，この感染症を「正しく恐れる，賢く恐れる」こと を促しながら，情報の報道も考え，悪影響が出ている 心身機能と日常生活内容を早々に改善すべきである. すなわち，感染の予防を強調するだけではなく，それ 以上に, 生活不活発抒よび人とのつながりの低下への 予防の重要性もしっかりと訴えかけるべきである.

また，自宅生活のさらなる充実化も必要である，筆 者の研究機構から, 単に外出頻度の問題だけではなく, 日常生活の大半の時間を過ごす自宅の生活内容におい ても，身近なヒントを拾い上げ，創意工夫をすること により, ワンランクアップした生活内容を実現するた めのノウハウとして「おうちえ」という情報を発信し ている4).

そこで， ウイズコロナ・ポストコロナ社会を見据え て，我が国がどのように大きく変容できるのかが大き

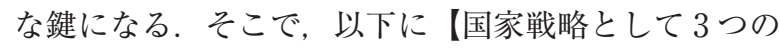
「守る」：(1)感染から守る, (2)経済問題から守る, (3) 健康・健全な地域社会を守る】を実現すべきであるこ とを改めて強調したい（図6)。その中で，個人だけ ではなく,「地域のニューノーマル」の構築へチャレン ジしたい.

まずは, 3 つの予防(感染予防, 生活不活発の予防, 人とのつながり低下への予防）を徹底しながら，さら に三密に配慮しながら, 従来の地域活動の再開と地域
の絆を戻していかなければならないことは言うまでも ない，それらを遂行していくなかで，住民（特に高齡 者）の変革と地域の変革のために「ハイブリッド型の 地域コミュニティ」を目指して行くことも視野に入れ るべきである，オンサイト（現場）で従来の通いの場 や集いの場を上手く配慮しながら実現させていく，そ こにオンライン技術を上手く溶け込ませ，地域支援 ICT プラットフォームを創造していくべきである. すなわち，感染対策に直結する新しい生活様式も当然 重要であるが, それに加えて，人とのつながり方や集 い方の新しい形をIT 技術の駆使により模索し,「身体 は離れていても心が近づくことが出来る地域社会」を 構築したい。 そこには趣味や価値観を共通項として, 物理的な距離が大きく離れている者同士（特に若い世 代だけではなく高齢者も）で気軽に集えるように，さ らには, 従来の地域コミュニティ（特に日常生活圈域） に打いて忘れかけられている「絆」を戻すことが出来 るようにしたい.

\section{さいぶに}

このコロナ問題によるピンチをどうチャンスに変え るのか, そしてへルスケア分野に扔いて, 国民の個々 人に何を伝え，さらには新たな地域社会づくりにどう 反映させるのか，ここは大きな分岐点になるだろう． この課題は，ポストコロナ時代において，人の QOL のあり方はどう変わっていくべきかを意味している. 健康上の不安を取り除き, 住み慣れた地域で自立した 生活を延伸し，生活の質（QOL）の維持向上を図る には, 高齢者の特性を踏まえた健康サポートが必要で ある。 なかでも疾病予防（特に生活習慣病の重症化予 防）と生活機能維持（特にフレイル予防〜介護予防） の両面にわたる視点が重要である。開業医・かかりつ け医による通常診療の中で, 医学的な診断や治療を進 めると同時に, フレイル健診により包括的な視点の情 報を得ることが出来る。まだコロナ禍が続くなかで, 地域の様々な社会資源等につなげる必要性が今まで以 上に必ず出てくる．ワクチン接種や治療薬の確立と同 時に，ご高齢者の日常生活全般にも十分に気を配りな がら, 社会的処方への意識も忘れてはならない. そし 
て地域全体として，真の人間中心社会に向けて,「我々 の忘れてはならない原点」と「次世代の新しい地域コ ミュニティ像（人のための新たなデジタル社会も含 む)」の両方を実現しながら，人と人との心を近づけ， 絆を感じ，豊かな社会にむけた新たな価值を全世代に 創造してくれることを信じてやまない.

著者の COI（Conflict of Interest）開示 : 本論文発表内 容に関連して特に申告なし

\section{文献}

1) Yamada M, Kimura $Y$, Arai $H$, et al.: Effect of the COVID-19 Epidemic on Physical Activity in
Community-Dwelling Older Adults in Japan: A CrossSectional Online Survey. J Nutr Health Aging 2020; 24 (9): 948-950.

2) Yamada M, Kimura Y, Arai H, et al: Recovery of Physical Activity among Older Japanese Adults Since the First Wave of the COVID-19 Pandemic. J Nutr Health Aging 2020; 24 (9): 1036-1037.

3）日本老年医学会：「新型コロナウイルス感染症」高齢 者として気をつけたいポイント. https://www.jpn-ge riat-soc.or.jp/citizen/coronavirus.html, 更 新 2020 年 3 月 13 日

4）新型コロナウイルス感染症 (COVID-19) に負けない. 高齢者の健康を守るために伝えたいこと．高齢社会総 合研究機構からのメッセージ「おうちえ」第 3 版（総 集 編). http://www.iog.u-tokyo.ac.jp/?p=4844, 更新 2020 年 5 月 24 日 